\title{
Factors affecting goat production in a communal farming system in the Eastern Cape region of South Africa
}

\author{
A.M. Mahanjana ${ }^{1}$ and P.B. Cronjée ${ }^{\#}$ \\ Department of Animal and Wildlife Science, University of Pretoria, Pretoria 0002, South Africa
}

\begin{abstract}
The aim of this survey was to characterize the economic, social and nutritional importance of goat farming in the Mgwalana district of the Eastern Cape region of South Africa, and to identify critical constraints and opportunities for use in future development initiatives. The majority (68\%) of de facto heads of households were males, of which $66 \%$ were older than 50 years of age. The majority (60\%) had received schooling for five years or less. Most respondents (86\%) kept goats. The mean flock size was 16 head, of which $76.7 \%$ consisted of does, $15.8 \%$ castrates and $7.5 \%$ bucks. The mean kidding percentage was $76 \%$ for maiden does and $64 \%$ for older does. The annual mortality rate was $7 \%$; adult does accounted for $47 \%$ of deaths, and abortions for $29 \%$. The main reasons given for keeping goats were for slaughter during traditional ceremonies (35\%) and for cash sales (23\%), and only $15 \%$ kept goats for home meat consumption. The motivation for the sale of goats was mainly to pay debts or save money (45\%) and to buy other foodstuffs (27\%). The majority of sales $(91 \%)$ took place during the summer months, and buyers (possibly migrant workers returning home during the Christmas vacation) used the goats mainly for traditional ceremonies, funerals and weddings. Only $10 \%$ of farmers indicated that they would invest in goat farming if granted a loan that had to be paid back. This would appear to be related to labour constraints, as $44 \%$ of goat owners herded their flocks themselves and 37\% relied on school-going children for this purpose. Only $19 \%$ of respondents indicated that they hired labour to herd their flocks. It would appear that future expansion of goat farming in this area is severely constrained by labour constraints and the fact that goat meat ranked lowest on the scale of eating preferences. It was concluded that initiatives aimed at improving the economic, nutritional and health status of this community through increased goat production are unlikely to be successful and that the problem of bush encroachment is likely to increase to the detriment of other ruminant species in the future.
\end{abstract}

Key words: goat, farming systems

${ }^{1}$ Present address: National Emergent Red Meat Producers Organization, P.O. Box 26151, Arcadia 0007, South Africa.

\#Author to whom correspondence should be addressed. E-mail: pbcronje@postino.up.ac.za

\section{Introduction}

Above average levels of malnutrition among humans, caused mainly by inadequate protein intake, are common in all the rural areas of the Eastern Cape region of South Africa (DBSA, 1994). One of the aims of this study was therefore to investigate the potential for increasing the intake of animal protein by improving the efficiency of goat production in this area. Goats are also important from an ecological perspective, as concern has been expressed at the impact of the apparent decline of goat numbers in recent years (2 856 in 1990 vs. 966 in 1994; Ciskei Veterinary Statistical Services, Bisho, 1994) on bush encroachment in many parts of the Eastern Cape. Bush encroachment constitutes a major management problem in grazing systems in savanna areas (Hurt \& Yeaton, 1991). Persistent invasion of the grass sward by the bush component is caused by under-utilisation of the bush component, and the introduction of browsers such as goats is an effective way of controlling control bush encroachment (Danckwerts \& Teague, 1989). The selection of the survey area was based on a need expressed by the Department of Agriculture (Middledrift district) to increase goat numbers as a means of controlling patches of bush encroachment in the area. This study was therefore conducted in order to characterize the economic, social and nutritional importance of existing goat farming systems in the Mgwalana district of the Eastern Cape region of South Africa, and to identify critical constraints and opportunities which could impact on the potential expansion of goat farming activities.

\section{Materials and methods}

The survey was conducted by way of personal interviews with communal farmers in the Mgwalana district. A structured questionnaire was designed to obtain information from respondents on socio-economic profiles, animal productivity, and goat utilisation and marketing profiles. The questions were posed in the language of the respondents, namely Xhosa. A sample of 100 households (20\% of the population) was selected at random using random number tables and a map of district households. 
The Mgwalana district occupies approximately 4000 ha and is situated south of the Amatola basin near Middeldrift in the Eastern Cape. The study area is approximately $100 \mathrm{~km}$ northwest of East London and $21 \mathrm{~km}$ southeast of Alice $\left(32^{\mathrm{O}} 39^{\prime} \mathrm{S}, 27^{\mathrm{O}} 00^{\prime} \mathrm{E}\right)$. Altitude varies from $490 \mathrm{~m}$ in the south to $1089 \mathrm{~m}$ in the north, and annual rainfall varies from 520 $\mathrm{mm}$ in the South to $700 \mathrm{~mm}$ in the north .The growing season (October-February) rainfall expectation is $284 \mathrm{~mm}$ in three years out of four. Mean minimum temperatures in July vary from $3-5^{\circ} \mathrm{C}$, and much of the district experiences frost between July and September, with occasional late frost up until November. The mean daily maximum temperature for January is $29^{\circ} \mathrm{C}$ (Institute for Planning Research, 1982). The greater part of the study area (70\%) is classified as false thornveld of the Eastern Cape (Acocks, 1975), and the balance is valley bushveld vegetation which occurs in the east along the Keiskamma River (Trollope \& Willis, 1989). The carrying capacity of the natural pasture has been assessed at 11 ha / animal unit (Hill, Kaplan, Scott \& Partners, 1977). The ratio of large stock to small stock has been estimated to be 1:3 (Mentis et al, 1981). Of the 4000 ha, approximately 2800 ha are used for grazing and 900 ha for dry-land crop production. The area is linked to the towns of Alice and Middeldrift by road, and bus and taxi services operate several times daily. The area has one day-care centre, one primary school, two secondary schools, as well as three general dealer stores. Approximately $14 \%$ of households have telephones.

\section{Results and discussion}

The majority (68\%) of de facto heads of households were males, of which $66 \%$ were older than 50 years of age. (mean age: 56 years). These figures contrast with the general perception that the majority of rural farmers are women. Nearly all respondents (89\%) were resident in the area, and $93 \%$ of those interviewed indicated that important management decisions such as the sale or slaughter of goats were their responsibility. A large proportion of the female de facto heads of households consisted of widows (58\%) of which $54 \%$ were older than 50 years. A second anomaly was the finding that the majority of goat owners had either been farming with goats for more than 20 years (41\%) or less than 10 years $(43 \%)$, and only $16 \%$ of respondents fell into the intermediate 10-20 year category. Although the reasons for these atypical distributions are unknown, it might be speculated that retrenchments in the mining industry and the downturn in the national economy during the past 10 years could have caused an influx to rural areas of older men who are less likely to be employed as migrant workers. The migration of younger people to urban areas might also be a factor contributing to the high proportion of elderly people in this population. Interestingly, a similar male to female ratio (2:1) was reported for an area of KwaZulu-Natal (Sokhela \& Bembridge, 1991).

Only eight percent of the respondents had more than eight years of schooling and only four percent had received post-matric or vocational training. The majority $(60 \%)$ had received schooling for five years or less. Similar results were reported by Bembridge (1987), who found that only five percent of respondents in the Ciskei area of the Eastern Cape region had received vocational training. Despite this, the majority of farmers were aware of differences in the relative nutritional value for goats of different species of trees (88\%) and bushes (76\%), and there was a high level of awareness of the benefits of immunization of goats against diseases (95\%), and of the negative effects of internal parasites (98\%). The majority (84\%) were aware of the changes brought about by different animal species to vegetation (both woody and grass components).

The general profile of the farming household in this area appears to be that of an aging adult community with relatively little formal schooling, but with a relatively good knowledge-basis of farming principles. This community is entrusted with the care of a relatively high proportion of resident school-going children (4 per household), of which the majority are probably grandchildren. The socio-economic status of this community is best illustrated by the fact that most of those interviewed indicated that their source of household income was from government pensions and money sent to them by non-resident parents of the children in their care (57\%). The fact that $38 \%$ of those interviewed indicated that they did not eat meat more frequently than once monthly, together with the practice of consuming meat from animals which have died from unknown causes (63\%) suggests that development initiatives related to animal protein production could have a substantial impact on the nutritional and health status of this community.

The majority of households (86\%) kept goats. The mean flock size was 16 head, of which $76.7 \%$ consisted of does, $15.8 \%$ castrates and $7.5 \%$ bucks. A similar distribution was evident in the case of kids less than one year of age (65.9\% does; $13.4 \%$ castrates; $20.7 \%$ bucks), indicating that does were preferentially retained within the system, while castrates and bucks were removed. This was confirmed by the finding that castrates accounted for $89 \%$ of goats slaughtered and $94 \%$ of those sold. The mean kidding percentage (number of kids born per doe per year) for maiden does was $76 \%$, and that of older does was $64 \%$. This figure is half that obtained for goats of similar genotype at the nearby Honeydale experimental station of the University of Fort Hare (142\%; number of kids born per doe mated). The disparity between the two age groups may be indicative of a low re-conception rate caused by an insufficient plane of nutrition. The annual mortality rate of animals was $7 \%$. Adult does accounted for $47 \%$ of deaths, and abortions for $29 \%$. The high incidence of abortions may be indicative of inadequate nutrition during the last trimester of pregnancy. In most cases the cause of death was cited as 
unknown and only $2 \%$ of respondents identified poor nutrition as a cause of death. Despite the comparatively low reproductive performance of goats, the majority of farmers classified the fertility of their animals as fair, and only $48 \%$ indicated that they would like to improve the fertility rate of their animals. The majority also classified the condition of their animals as good, and only $5 \%$ of respondents were not satisfied with the condition of their goats. These opinions are paradoxical, given the fact the number of ewes giving birth was rated as the most important aspect of goat farming (Table $1)$.

Table 1 Importance of goat production traits among farmers in the Mgwalana district of the Eastern Cape. Data for each ranking are expressed as a percentage of the total for all rankings within that particular trait. The most frequent ranking for each trait is indicated by shaded values.

Ranking $(1=$ most important, $9=$ least important $)$

\begin{tabular}{llllllllll} 
Trait & 1 & 2 & 3 & 4 & 5 & 6 & 7 & 8 & 9 \\
\hline Number of does kidding & & & & & & & & & \\
Number of kids born per doe & 24.1 & 48.1 & 9.3 & 9.3 & 3.7 & 1.9 & 3.7 & 0 & 0 \\
Mothering ability & 33.3 & 20.4 & 22.2 & 11.1 & 5.6 & 0 & 1.9 & 5.6 & 0 \\
Growth rate up to one year of age & 22.2 & 9.3 & 40.7 & 22.2 & 3.7 & 0 & 1.9 & 0 & 0 \\
Growth rate after one year of age & 1.9 & 0 & 9.3 & 33.2 & 19.7 & 16.7 & 13.0 & 9.3 & 0 \\
Mature size & 0 & 3.7 & 3.7 & 11.1 & 27.8 & 11.1 & 25.9 & 13 & 3.7 \\
Resistance to disease up to one year of age & 5.6 & 9.3 & 14.8 & 22.2 & 13.0 & 24.1 & 1.9 & 9.3 & 0 \\
Resistance to disease after one year of age & 1.9 & 5.6 & 5.6 & 7.4 & 14.8 & 16.7 & 29.6 & 16.7 & 0 \\
Coat colour & 1.9 & 1.9 & 1.9 & 1.9 & 0 & 0 & 1.9 & 1.9 & 88.9 \\
\hline
\end{tabular}

Similarly, although there was a high level of awareness of the negative effects of internal and external parasites on animal health, the majority only treated their goats against external parasites "when instructed to do so by the state veterinarian", and never de-wormed their animals. Although all were of the opinion that immunization of animals was necessary, only $4 \%$ indicated that they would call the veterinarian when an animal fell ill, died or aborted. In the majority of cases (59\%) sick animals were treated by the farmers themselves using traditional herbal remedies. These attitudes towards preventative health care can perhaps be explained by the perceptions that goats were seldom ill (60\%) and that intestinal parasites were seldom observed to be present in the gut of slaughtered animals. Conventional management practices such as planned breeding, replacement culling, pasture management and record keeping were not implemented. Does and rams were never separated, and there was no fixed age or time for castration of bucks. When respondents were asked to provide reasons for not practising controlled breeding, $90 \%$ attributed this to the communal land tenure system (i.e. non-existence of camps and fencing) and to a lack of labour or time. These constraints are in agreement with those identified by McDowell (1972) and De Haas and Horst (1979) who found that the degree of sophistication of husbandry or management practices is closely associated with systems of land tenure and prevailing environmental conditions.

In contrast to the commercial sector, each livestock species has a specific role in communal livestock systems that is not necessarily related to the generation of cash income (Bembridge, 1984). It was evident that goats fulfil a multipurpose role in the Mgwalana community. The main reasons given for keeping goats (Figure 1) were for slaughter during traditional ceremonies (35\%) and cash sales (23\%). The majority of adult goats (mainly castrates) were sold for relatively good prices (between R300 and R400 in 1996). It is significant that only 15\% of the respondents kept goats for home meat consumption. Almost all the respondents (85\%) who indicated that they did slaughter goats only did so on special occasions such as family festivities (birth of a child, marriage and birthdays of dead relatives). It is also evident (Figure 1) that although goats are widely used for ceremonial purposes, they are also used to accumulate and store wealth as a hedge against emergencies. These findings are similar to those of Steyn (1988) who reported that $86 \%$ of farmers at Lujiko and Nyaniso in the Ciskei indicated that goats were used for traditional ceremonial purposes. Goats were widely used for sacrificial purposes to placate ancestral spirits or as an offering of thanks for good fortune. 


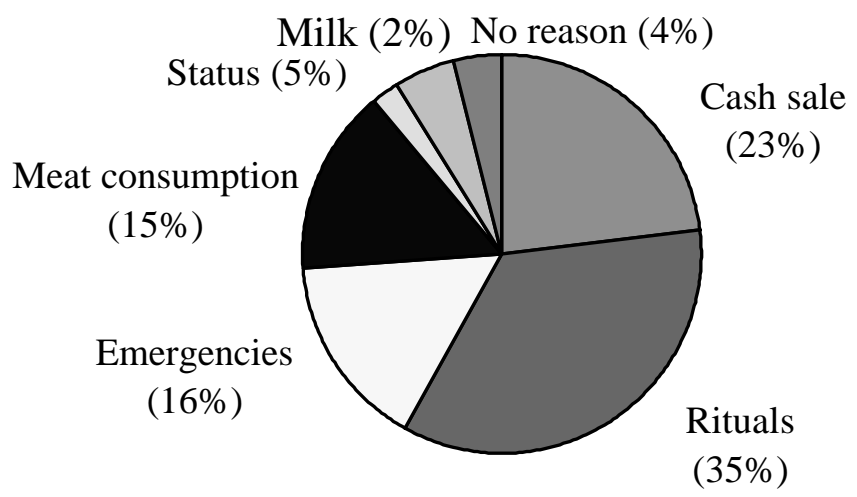

Figure 1 Most important reasons given for keeping goats among farmers in the Mgwalana district of the Eastern Cape region.

The motivation for the sale of goats was mainly to pay debts or save money (45\%) and to buy other foodstuffs (27\%). The majority of sales (91\%) took place during the summer months, and buyers (possibly migrant workers returning home during the Christmas vacation) used the goats mainly for traditional ceremonies, funerals and weddings. The selling of goats for cash also featured prominently in the study of Steyn (1988). White-coloured goats were in high demand for sacrificial purposes, and comparatively high prices were paid for them. In contrast, the coat colour was rated as the least important trait related to goat production in the Mgwalana district (Table 1). Goat skins were either sold for cash (76\%) or retained for personal use (24\%), such as the making of house mats or cattle whips. Goat sales took place on an informal basis, and no goats were sold by auction, or to abattoirs or butchers. Although goat milk is widely used in Europe and other parts of Africa, only $30 \%$ of respondents indicated that they utilised milk from goats. It was not possible to accurately determine milk yields, but an estimate of $500 \mathrm{ml}$ per goat per day was given. Individual does were occasionally milked once daily, and the milk was consumed by the elderly or by infants. The reasons for the low consumption of goat milk deserves further investigation, as goat milk represents an under-utilised source of nutrients that could improve the nutritional and health status of the community.

When asked to rank various types of meat, including fish, with regard to how frequently they would like to consume them, respondents indicated a preference for mutton and poultry while fish and goat were the least popular choices (Table 2).

Table 2 Ranking of meat consumption preferences among farmers in the Mgwalana district of the Eastern Cape. Data for each ranking are expressed as a percentage of the total for all rankings within that particular trait. The most frequent ranking for each trait is indicated by shaded values.

\begin{tabular}{lllllllll}
\hline & \multicolumn{8}{c}{ Ranking } \\
Trait & 1 & 2 & 3 & 4 & 5 & 6 & 7 \\
\hline & & & & & & & \\
Mutton & 47.5 & 40 & 8.8 & 2.5 & 1.3 & 0 & 0 \\
Poultry & 40 & 28.8 & 17.5 & 8.8 & 2.5 & 2.5 & 0 \\
Beef & 8.8 & 17.5 & 36.3 & 21.3 & 13.8 & 2.5 & 0 \\
Pork & 2.8 & 5.6 & 23.6 & 40.7 & 16.7 & 8.3 & 0 \\
Goat & 0 & 2.5 & 6.3 & 15.2 & 40.5 & 34.2 & 1.3 \\
Fish & 1.4 & 4.3 & 14.5 & 14.5 & 26.1 & 37.7 & 1.4 \\
\hline
\end{tabular}


The reason for discrimination against goat meat was attributed to its taste and smell by $76 \%$ of the respondents. Consumer preferences for goat meat and mutton have been shown to be associated with cultural practices and socioeconomic status (Casey, 1992; Kirton, 1992). Pascall (1990) ascribed the discrimination against goat meat to the practice of marketing meat from more mature animals, and recommended that goats be slaughtered at a live mass not exceeding 35$40 \mathrm{~kg}$ to avoid consumer aversion. Els (1995) observed a tendency among rural African communities to slaughter fully mature and old animals. This apparent paradox may be explained by the fact that chewable meat is preferred to tender meat among African communities (Kirton, 1992); this preference would be satisfied by the slaughter of mature animals, albeit to the detriment of flavour and aroma.

A large proportion of farmers indicated that they had no desire to attend goat-farming courses (55\%) or belong to a goat study group (53\%). The prevalent attitude towards goat farming is best illustrated by the fact that only $10 \%$ of farmers indicated that they would invest in goat farming if granted a loan that had to be paid back (Figure 2).

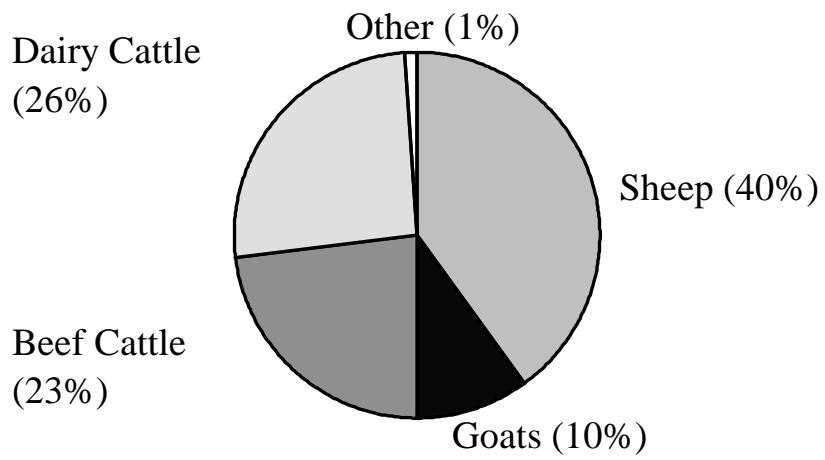

Figure 2 Preferred livestock enterprise among farmers in the Mgwalana district of the Eastern Cape region.

Sheep farming was the most preferred livestock enterprise in this community, followed by dairy and beef. The preference for sheep farming may be attributed to the fact that sheep are more docile than goats and can be herded together with cattle. The lack of enthusiasm for investing in goat production appears to originate from the perception that goats are difficult to manage. When farmers were asked to identify the major constraint pertaining to goat farming, the majority of replies related to managerial difficulties: goats were perceived as being hard to manage and were characterized as 'naughty', 'wild', 'greedy' and 'unmanageable'.

It is probable that the preference for animals that are less troublesome to herd was related to labour constraints, as $44 \%$ of goat owners herded their flocks themselves and 37\% relied on school-going children for this purpose. Only $19 \%$ of respondents indicated that they hired labour to herd their flocks. In this system, considerable labour and time must be expended to locate and return goat flocks to a kraal each night to protect them against predators and theft. Kids are confined to the kraal during both day and night to prevent losses and also to ensure better supervision. In most areas, the fencing that separates arable allotments from the communal grazing area is in poor condition, and constant supervision is necessary to ensure that goats do not gain access to and consume crops intended for human consumption. It is also significant to note that although $89 \%$ of respondents were full-time residents in the area, $43 \%$ had day-jobs in the local towns and were not present during the day. The majority of those present in the Mgwalana area during working hours were pensioners. These results strongly indicate that initiatives aimed at increasing the numbers of adult goats would probably not find acceptance among this community.

\section{Conclusions}

In general terms, the profile for this area portrays a biologically and economically viable goat production system that could be improved considerably. On these grounds alone, it would appear that a goal of increased animal protein production could be attained through development initiatives aimed at expanding and improving goat production among farmers in this community. In practice, however, several factors mitigate against the success of such a course of action: it would also appear that the future of goat farming in this area is severely limited by labour constraints and the fact that goat meat ranked lowest on the scale of eating preferences. These results indicate that initiatives aimed at improving the economic, nutritional and health status of this community through increased goat production are unlikely to be successful and that the problem of bush encroachment is likely to increase to the detriment of other ruminant species in the future. 


\section{References}

Acocks, J.P.H., 1975. Veld types of South Africa. Memoirs of the botanical survey of South Africa, No. 40. Department of Agricultural Technical Services, Pretoria, South Africa.

Acocks, J.P.H., 1988. Veld types of South Africa, 3rd edition. Memoirs of the botanical survey of South Africa, No. 57. The government printer, Pretoria, South Africa.

Bembridge, T.J., 1984. A systems approach to the study of agricultural problems in Transkei. Ph.D. dissertation, University of Stellenbosch, Stellenbosch, South Africa.

Casey, N.H., 1992. Goat meat in human nutrition. In: Proceedings of the fifth international conference on goats Vol. 2, Part II, 582-596.

Danckwerts, J.E. \& Teague, W.R., 1989. Veld management in the Eastern Cape. Department of agriculture and water supply. The government printer, Pretoria.

De Haas, H.J. \& Horst, P., 1979. The significance of goat production for covering protein requirements. In: Animal research and development: a biennial collection. Vol. 9. Laupp \& Göbel, Tübingen, Germany.

DBSA, 1994. South Africa's nine provinces: a human development profile. Development bank of South Africa, Halfway House, Midrand, South Africa.

Els, J.F., 1995. Production analysis of a Boer goat flock in bush Savanna veld. M.Sc. thesis,University of Pretoria, Pretoria, South Africa.

Hill, Kaplan, Scott \& Partners, 1977. Keiskama river basin survey. Vol. 11, Chapter 13. Dmbaza Printers, Ciskei Government, Bisho, South Africa.

Hurt, C.R. \& Yeaton, R.I., 1991. Successional Dynamics of Savana: A matrix-modelling approach. In: Proceedings of the international conference of the grassland society, Pretoria, South Africa. Paper 3.

Institute for planning research, 1982. Strategy and guidelines for the physical development of the Republic of Ciskei. Vol. 2, Atlas, University of Stellenbosch, South Africa.

Kirton, A.H., 1992. Goat meat production and processing. In: Proceedings of the fifth international conference on goats Vol. 2, Part II, pp 436-439.

McDowell, R.E., 1972. Improvement of livestock production in warm climates. W.H. Freeman and Company, San Francisco.

Mentis, M.T., Curtis, N., O'Reagain, P.J., Stuart-Hill, G.C. \& Trollope, W.S.W., 1981. The grazing and browsing capacity of the Amatola Basin. Report No. 4/81, A.R.D.R.I., University of Fort Hare, Alice, South Africa.

Pascall, D., 1990. The Boer goat in Zimbabwe. Farming World. March. pp 3-5.

Sokhela, M.P. \& Bembridge, T.J., 1991. A comparative study of the impact of small-scale cane growing in KwaZulu. S. Afr. J. Agric. Ext. pp. 45-51.

Steyn, G.J., 1988. A farming system study of two rural areas in the Peddie district of Ciskei. Ph.D. dissertation, University of Fort Hare, Alice, South Africa.

Trollope, W.S.W. \& Willis, M.J., 1989. Assessment of veld conditions in Ciskei: a report on a new technique of veld condition assessment. University of Fort Hare, Alice, South Africa. 